STUDI

FRANCESI

\section{Studi Francesi}

Rivista quadrimestrale fondata da Franco Simone

170 (LVII | II) | 2013

Varia

\title{
Gerald Nachway, Scapegoats and Conspirators in the Chronicles of Jean Froissart and Jean le Bel
}

\section{Paola Cifarelli}

\section{(2) OpenEdition}

1 Journals

\section{Édition électronique}

URL : https://journals.openedition.org/studifrancesi/3023

DOI : 10.4000/studifrancesi.3023

ISSN : 2421-5856

Éditeur

Rosenberg \& Sellier

\section{Édition imprimée}

Date de publication : 1 juillet 2013

Pagination : 436

ISSN : 0039-2944

\section{Référence électronique}

Paola Cifarelli, « Gerald Nachway, Scapegoats and Conspirators in the Chronicles of Jean Froissart and Jean le Bel », Studi Francesi [En ligne], 170 (LVII | II) | 2013, mis en ligne le 30 novembre 2015, consulté le 02 février 2023. URL : http://journals.openedition.org/studifrancesi/3023 ; DOI : https://doi.org/ 10.4000/studifrancesi.3023

Ce document a été généré automatiquement le 2 février 2023.

\section{(c)}

Creative Commons - Attribution - Pas d'Utilisation Commerciale - Pas de Modification 4.0 International - CC BY-NC-ND 4.0

https://creativecommons.org/licenses/by-nc-nd/4.0/ 


\title{
Gerald Nachway, Scapegoats and Conspirators in the Chronicles of Jean Froissart and Jean le Bel
}

\author{
Paola Cifarelli
}

\section{RÉFÉRENCE}

GERALD NACHWAY, Scapegoats and Conspirators in the Chronicles of Jean Froissart and Jean le Bel, «Fifteenth Century Studies», 36, 2011, pp. 103-125.

1 Les rapports étroits qui unissent les Chroniques de Froissart et les Vrayes Chroniques de Jean Le Bel, qui concernent les débuts de la Guerre de Cent Ans, ne sont pas à démontrer; l'A. focalise son attention sur la section qui traite du soulèvement connu sous le nom de Jacquerie et adopte un point de vue à la fois historique et littéraire pour mettre en évidence, par-delà des similitudes évidentes, la diversité des propos et des styles qui sous-tend les deux ouvrages. En particulier, le contexte plus vaste dans lequel Froissart insère la révolte paysanne lui permet de préciser les responsabilités de la noblesse, mais aussi de souligner la valeur de l'acte héroïque; du point de vue littéraire, le potentiel dramatique des événements en question est exalté et le rôle héroïque des chevaliers peints par Froissart est comparable à celui des protagonistes des chansons de geste. 